\title{
Die ontwikkeling van 'n paradigma vir die skryf van 'n kinderverhaal'
}

Leentjie Theron \& Hans du Plessis

ATKV-skryfskool

Potchefstroomse Universiteit vir $\mathrm{CHO}$

POTCHEFSTROOM

\begin{abstract}
The American linguist, William Labov, distinguished six elements underlying a well-structured oral narrative. These elements are, in the course of this article, developed into a paradigm which can be used in the writing of a children's story.

Against the background of the sociolinguistics of Labov's analysis the elements are further placed within Mary Louise Pratt's narratological approach.

The elements are then applied to children's literature. Published and unpublished children's stories are analysed with reference to the elements indicated by Labov. On the basis of the analysis the elements are developed into a paradigm in the Creative Writing sense of the term.
\end{abstract}

\section{Inleiding}

Die Amerikaanse linguis, William Labov (1976), identifiseer ses elemente binne die mondelinge vertelling, naamlik: uittreksel, oriëntasie, verwikkelde handeling, evaluering, resultaat en die coda.

Die mondelinge vertelling word as 'n natuurlike manier van vertel gesien. Die elemente wat vir die natuurlike vertelling onderskei kan word, behoort logieser-

1 Hicrdic artikel is gebascer op 'n gedeclte van 'n Magisterverhandeling wat voltooi is onder leiding van prof. Hans du Plessis (PU vir CHO). Kyk Theron (1993). 
wys ook vir die meer gestruktureerde vertelling te kan geld, en Labov se analise is ook reeds op die Afrikaanse vertelling deur onder andere Du Plessis (1984) en Prinsloo (1987) toegepas. In haar analise plaas Mary Louise Pratt (1977) hierdie model binne die literatuurteorie.

Die doel van hierdie artikel is om na aanleiding van die genoemde navorsing ' $n$ paradigma te postuleer wat op die skryf van 'n kinderverhaal toegepas kan word. Data uit die woordkunspraktyk, spesifiek die kinderverhaal, word geanaliseer om dan op dié wyse vas te stel in welke mate dit moontlik is om op grond van die teorie 'n paradigma te postuleer.

\section{Die Labov-metode}

Labov (1976) maak 'n studie van dialektiese variasie in swart Amerikaanse Engels. Hy maak opnames waar mense van hulle persoonlike belewenisse vertel. By die ontleding van hierdie vertellings kom Labov tot die gevolgtrekking dat mense ' $n$ natuurlike vermoë besit om stories te vertel. Labov se gebruik is 'n linguistiese, variasiekundige benadering.

\subsection{Die elemente}

\subsubsection{Uittreksel}

Die uittreksel dien as 'n soort aankondiging. Hierdie aankondiging kan enige vorm aanneem, byvoorbeeld 'ek wil julle hierdie een vertel ...' of 'het julle die storie gehoor van ..?'. Die uittreksel kan ook die vorm aanneem van 'n opsomming van die gebeure, maar dit is nie noodwendig die inleiding van ' $n$ geskrewe vertelling nie - dit sou eerder die wyse wees waarop die verteller die aandag van die hoorder verkry. Toegepas op 'n geskrewe teks sou die uittreksel ook die titel kon wees, hoewel dit ook deel van die teks (veral die begin) self kan wees.

\subsubsection{Oriëntasie}

Die element oriëntasie sou ook met die benaming storiekonleks vervang kon word. Oriëntasie geskied dwarsdeur 'n vertelling, omdat dit hoofsaaklik gebruik word om 'n tweede deiktiese sentrum te stig. Met deiktiese sentrun word bedoel die middelpunt van tyd, ruimte en persoon. Combrink (1981:93) noem dat deiktiese sentrum in die eerste instansie die sprekersposisie ten tye van spreke is. Dit is dus logies dat daar vir alle vertellings twee deiktiese sentrums moet bestaan: die werklike deiktiese sentrum, die sentrum waarin die verteller en die hoorder verkeer en die fiktiewe deiktiese sentrum, die sentrum van die vertelling. Die verteller stig met ander woorde die fiktiewe deiktiese sentrum sonder om die 
werklike deiktiese sentrum op te hef. Volgens Labov kan daar ten opsigte van tyd, ruimte of persoon na enige van die twee deiktiese sentrums verwys word.

\subsubsection{Verwikkelde handeling}

Labov (1976:360) beskryf verwikkelde handeling as "the core of the narrative". Verwikkelde handeling vonn die enigste essensièle element van 'n vertelling. Daar word op die gebeure self gekonsentreer. In die verwikkelde handeling word algemeen van die geselshistoriese presens gebruik gemaak, maar daar kan by geleentheid na die grammatiese verlede tyd oorgeslaan word.

'n Ander linguistiese middel wat in die verwikkelde handeling opval, is die spreker se gebruik van naamwoorde om te verwys. Aan die begin word die leksikale naamwoordstukke neutraal gebruik om referente te identifiseer, maar hoe verder die verwikkelde handeling vorder, hoe ingewikkelder raak die netwerk van tipeen tekenanaforiese verwysing. Hieronder sou byvoorbeeld die vertelekonomiese gebruik van hom as anafoor vir sowel menslike as niemenslike antesedente ressorteer.

\subsubsection{Evaluering}

Met hierdie element word aangedui waarom dit in die vertelling gaan, met ander woorde, waarom die vertelling vertellenswaardig is. Hierdeur verskaf die verteller ook die antwoord op die hoorder se moontlike vraag: 'Wat daarvan?'

There are many ways to tell the same story, to make very different points, or to make no point at all. Pointless stories are met (in English) with the withering rejoinder, 'So what?'... . (Labov, 1976:371.)

Evaluering kom nie op 'n bepaalde plek in die vertellingstruktuur voor nie, maar kom verspreid in die vertelling voor. Die algemene tendens is egter om die evaluering voor die resultaat in 'n mondelinge vertelling te plaas. Evaluering geskied egter ook soms deurlopend in 'n vertelling, om sodoende 'n sekondêre struktuur te vorm.

Sou evaluering in 'n vertelling ontbreek, ontstaan 'n betekenislose geheel, ' $n$ pointless story.

Die vertelling kan dus op verskeie maniere aangebied word om verskillende argumente te staaf en die evaluering speel in hierdie verband 'n belangrike rol.

Evaluering kan op verskeie maniere geskied byvoorbeeld: 
* Deur evaluerende kommentaar, waarin die verteller die vertelling onderbreek om te verduidelik/bevestig wat die doel van die vertelling is. Hierdie onderbreking kan ekstern wees: die verteller sal self 'n stelling maak, byvoorbeeld: Dit was 'n vreeslike ondervinding.

* Deur die evaluerende stellings in te sluit in die vertelling. Die verteller vertel byvoorbeeld hoe hy op daardie oomblik gevoel het: Ek het maar my ö̈ toegedruk en gedink dit is my einde.

* Die verteller kan vertel wat hy aan 'n ander karakter in die vertelling gesê het of evaluerende opmerkings van 'n ooggetuie kan aangehaal word.

Bogenoemde wyses van evaluering is onopsigtelik. Onopsigtelike wyses van evaluering is baie meer effektief in 'n vertelling. In Labov se terme sal gepraat kan word van ' $n$ ingebedde evaluering.

Evaluering kan ook deur sintaktiese middele, soos in die narratiewe clause weergegee word. Labov (1976:378) deel hierdie sintaktiese elemente onder vier hoofde in:

\subsubsection{Intensiveerders}

Deur middel van intensiveerders word gepoog om ' $n$ bepaalde gebeurtenis te versterk. Die gebeurtenis kan geïntensiveer word op die volgende wyses:

- Gebare: in 'n geskrewe stuk sou dit vervang kon word met geluide wat in die teks nagemaak word. In 'n vertelling vergesel dit gewoonlik 'n deiktiese hierdie of daardie.

- Fonologiese klem: verlenging van vokale of ander geluide.

- Kwantifiseerders: heeltemal word dikwels as 'n intensiveerder aangewend.

- Herhaling.

- Konvensionele uitdrukkings.

Bogenoemde intensiveerders word gebruik om 'n situasie te merk en te evalueer.

\subsubsection{Vergelykers}

Onder vergelykers noem Labov (1976:381) dat die volgende as middel tot evaluering gebruik kan word: 


\section{- Die negatief}

Hierdie metode kom dikwels voor by evalueringsgedeeltes. Hierdeur ontstaan 'n evalueringswyse van gebeure deur hulle te plaas teen die agtergrond van ander gebeure wat moontlik kon plaasgevind het, maar nie plaasgevind het nie. Voorbeeld:

Nou ja, ek dink hulle was glad nie sulke slegte ambassadeurs vir ons land nie, al was dit nou vir hulle dalk ongerieflik. Nou wonder ek partykeer of ons politici nie dalk iets uit hierdie insident behoort te leer nie. Ek is nou nie seker wat hulle behoort te leer nie.

- Vrae

Vrae wat openlik evaluerend is en wat tot die hoorder gerig is, kom dikwels voor. Soms kan dit ook geïmpliseerde dreigemente wees wat in die woorde van karakters ingebed is. Voorbeeld: Dink jy nie dit is erg nie?

\section{- Imperatief}

'n Voorbeeld van die gebruik van die imperatief kan wees: Jy doen dit of ...

Die bevel hou met ander woorde dikwels ' $n$ dreigement in.

\subsubsection{Korrelate}

Labov (1976:389) onderskei hoofsaaklik tussen drie tipes korrelate:

* Die gebruik van dubbele attributiewe. Volgens Labov kom dit selde in vertellings voor.

Die geweldige hoë berg.

* Die gebruik van verskillende leksikale naamwoordstukke met dieselfde verwysings:

Ons het vir hom 'n motor gekoop, so 'n mooi rooie, waarmee hy kan werk toe ry.

* Onderbreking van ' $n$ handelingsgeheel:

Sy was so bly, ek kon sien, sy was bly. 


\subsubsection{Verklarende beskrywings}

Verklarende beskrywings kan 'n evaluerende funksie hê in die sin dat dit verklarend kan wees van bepaalde karaktereienskappe.

Labov (1976:396) merk ten opsigte van verklarende beskrywings op: "The most highly evaluated form of language is that which translates our personal experience into dramatic form."

Die hoofdoel van verklarende beskrywings is dus om 'n narratiewe gebeurtenis te intensiveer.

\subsubsection{Resultaat}

Die vraag na wat uiteindelik gebeur het, word in hierdie gedeelte beantwoord. Labov (1976:363) noem dit: "the termination of the series of events". Die resultaat impliseer die uiteinde in dié sin dat die hoorder nie meer 'en toe?' sal vra nie.

\subsubsection{Coda}

Die coda sluit die vertelling af. Die verteller en die hoorder word daarmee terug gebring na die punt waar die vertelling begin is; daar word met ander woorde teruggekeer na die oorspronklike deiktiese sentrum. Die fiktiewe deiktiese sentrum word dus opgehef en daar is 'n terugkeer na die werklike deiktiese sentrum. Tradisioneel word 'Fluit, fluit, my storie is uit!' as coda gebruik.

'n Coda kan gevorm word deur:

- $\quad$ vrye clause aan die einde van die vertelling;

- algemene waarmemings of

- $\quad$ 'n aanduiding van die uitwerking van die gebeure op die verteller.

Die term coda is ontleen aan die musiek, 'n term wat in sommige musiekstukke die afsluiting aandui.

\section{Mary Louise Pratt}

Vroeg in die twintigste eeu het literatuurteoretici 'n toenemende belangstelling in die moderne linguistiek begin toon. Sowel die Russiese Formaliste as die Praagse Skool het van die veronderstelling uitgegaan dat daar 'n verskil tussen gewone en poëtiese taal bestaan 
Mary Louise Pratt (1977) gaan van die veronderstelling uit dat die literêre diskoers 'n bepaalde gebruik van taal is en nie ' $n$ soort taal op sigself nie. Sy is ook van mening dat die feit dat daar vandag nog geglo word dat daar 'n wesenlike verskil tussen gewone taalgebruik en literêre taalgebruik bestaan, verantwoordelik is vir die feit dat daar nog géén bevredigende literêre teorie ontwikkel kon word nie (Pratt, 1977:xii). Sy ondersoek literêre tekste uitsluitlik om aan te toon hoe die struktuur, die taal en die kommunikasiesituasie in literêre werke ooreenstem met normale taalsituasies.

Pratt (1977:xii) formuleer die hoofdoel van haar studie as:

(T)o describe other types of utterances. Departing from the claim that literary discourse must be viewed as a use rather than a kind of language, I have advanced the hypothesis that a descriptive apparatus which can adequately account for the uses of language outside literature will be able to give a satisfactory account of literary discourse as well.

Pratt (1977:86) vind ondersteuning vir haar teorie in die sosiolinguistiese navorsing van Labov en die taalhandelingsteorie en gaan van die veronderstelling uit dat literêre werke ook taalhandelinge is en gevolglik ook van konteks afhanklik is:

And with any utterance, the way people produce and understand literary works depends enormously on unspoken, culturally-shared knowledge of the rules, conventions, and expectations that are in play when language is used in that context.

Olıman (vergelyk Cloete, 1984:5) wys daarop dat taalhandeling in die literêre werk nageboots word en die leser 'n spreker en konteks moet verbeel. Pratt (1977:96) verskil egter hiervan:

Those characteristics of the literary speech situation which Ohman attributes to a work being a quasi-speech-act are actually characteristics of the real speech acts that the literary works purportedly imitate.

'n Taalhandelingsbenadering ten opsigte van die letterkunde kan beskryf word in dieselfde terminologie as alle ander gesprekke en die letterkunde kan dus geïntegreer word binne die breë taalopset - soos alle ander kommunikatiewe aktiwiteite. Pratt (1977:86) regverdig hierdie studie só:

In sum, speech act theory provides a way of talking about utterances not only in terms of their surface grammatical properties but also in terms of the context in which they are made, the intentions, attitudes and expectations of the participants, the relationships existing between participants, and generally, the unspoken rules and conventions that are understood to be in 
play when an utterance is made and received ... literature itself is a speech act.

Dit spreek vanself dat binne die kommunikasiesituasie waarin die literêre teks geplaas word, ons te make het met 'n pragmatiese situasie waarin veral die situasiekonteks beklemtoon word. Anker (1987:5) noem ook dat verskeie ondersoekers van die letterkunde en taalhandelingsteorie juis die leser se begrip van hierdie situasiekonteks van kommunikasie beklemtoon as essensieel vir die verstaan van die boodskap. Die outeur/spreker moet dus die leser oriënteer ten opsigte van die inhoud van die gerepresenteerde wêreld wat eerstens 'n oriëntering ten opsigte van plek en tyd impliseer.

Labov se model word as vanselfsprekend gesien in dié sin dat (i) die vertel van 'n persoonlike ervaring 'n taalhandeling is wat almal ken en al beoefen het. Soos vroeër genoem is, beskik mense oor 'n natuurlike aanvoeling vir die wyse waarop so 'n vertelling aangebied moet word en (ii) is daar 'n duidelike ooreenkoms tussen die ses onderafdelings van naturlike stories en die ontwikkelingsgang in verhalende literatuur volgens tradisonele opvatting.

Die gevolgtrekking wat gemaak kan word, is dat sowel die vertelling as verhalende literatuur die verwoording van ondervindings is - en juis daarom is dit logies dat albei struktureel dieselfde bou vertoon. Pratt (1977:67) bevestig hierdie redenasie met "perhaps the best proof of this pudding is the frequency and ease with which the natural narrative speech situation is reproduced and imitated in narrative literary works".

In die ondersoek bevind Pratt dat verhalende literatuur ook die ses struktuurelemente - soos deur Labov geïdentifiseer - bevat. Die elemente kom weliswaar in ander gestalte na vore, maar die feit bly staan dat die elemente ook in verhalende literatuur voorkom. Die verskil in voorkoms kan veral toegeskryf word aan die feit dat die literêre werk ook bepaalde artistieke kwaliteite bevat wat dan aanleiding gee tot die verskil in voorkoms wat die elemente aanbetref.

In verhalende literatuur kom die uittreksel onder meer in die vorm van 'n titel en subtitels voor. Die verskil is daarin geleë dat titels en subtitels bepalend is. Pratt (1977:61) noem egter dat die verskil geleë is in die verskil tussen geskrewe en gesproke diskoers en nie in 'n verskil in funksie nie. In natuurlike stories vervul die uittreksel dikwels die funksie van 'n uitnodiging aan die luisteraar. Die luisteraar word dus uitgenooi om die rol van die gehoor te vervul. Titels nooi die leser ook dikwels uit om die rol van die leser te vervul.

Waar die verteller van natuurlike stories die verhaal by iemand anders te hore gekom het, beroep die verteller hom by wyse van die evaluering in die uittreksel 
op die geloofwaardigheid daarvan. In die geval van verhalende literatuur is die bevestiging van geloofwaardigheid dikwels in die uittreksel geleë. As voorbeeld hiervan kan 'n Droë wit seisoen (1979) van André P. Brink voorgehou word. Uit die voor- en nawoorde tot die verhaal blyk dit dat die verteller 'n jeugvriend van Ben du Toit is aan wie hy (Ben du Toit) kort voor sy dood alle dokumente in verband met die verhaal verskaf. Hierdie procédé skep beslis die illusie van geloofwaardigheid.

Dit spreek vanself dat die oriëntering van verhalende literatuur vanweë die lengte meer uitgebreid en volledig sal wees. Dikwels word die oriëntering - in verhalende literatuur - in paragrawe weergegee. In modeme literatuur word die doelbewuste weglating van oriëntering egter dikwels aangetref. Pratt (1977:53) is van mening dat volwasse lesers 'n gemerkte teks (in medias res) ten volle kan hanteer. Volwasse lesers hanteer 'n teks as 'gemerk' en as sodanig is dit dus ten volle georiënteerd. In die geval van natuurlike stories sou dit 'n fout wees om die hoorder nie te oriënteer nie. Die verteller het 'n veel groter verpligting as die skrywer ten opsigte van oriëntasie. Ook die skrywer van kinderliteratuur moet ten opsigte van oriëntasie 'n veel groter inset lewer. In 'n volgende gedeelte sal aangetoon word in hoe ' $n$ mate die illustrasies van 'n teks bydra tot die oriëntering.

Ten opsigte van evaluering kan Labov se onderskeid feitlik in dieselfde mate geld vir verhalende literatuur. Eksteme evaluering is voor die hand liggend en kom algemeen voor in veral kinderliteratuur. Ook met dialoog kan evaluering baie effektief toegepas word. Pratt (1977:63) noem ook ten opsigte van bogenoemde:

As in Labov's data, it is in novelistic passages like these that we find the highest concentration of comparative constructions, complex auxiliaries, metaphors, and so on. All the evaluative devices Labov described in natural narrative are there in literary narrative and they perform the same function in both types.

Ten opsigte van vertellers en fokalisasie as middel tot evaluering, moet verwys word na André P. Brink se Houd-den-Bek. Hierdie verhaal bevat dertig vertellers, van wie die hooffiguur, Galant, die konvergensiepunt van die vertelling is. Hierdie procédé skep baie beslis geloofwaardigheid.

Evaluering kom vervleg deur 'n verhaal voor en vorn sodoende 'n sekondêre struktuur. Soos reeds genoem is, kan evaluering ook in die uittreksel geleë wees. Ten opsigte van natuurlike stories kom evaluering dikwels direk voor die resultaat voor.

Wat is dan die belangrikleid van die feit dat verhalende literatuur op dieselfde wyse ontleed kan word as natuurlike stories? In die eerste plek plaas dit 'n 
vraagteken oor die Formaliste se siening dat literêre taalgebruik outonoom is (Pratt, 1977:68).

Die Formaliste se onderskeid tussen fabula ('n storie) en sjuzel (weergawe van die storie) is gelyk aan Labov se onderskeiding tussen narrative core en die secondary structure. Pratt (1977:68) stel dit só:

Labov's 'intensifiers' and 'comparators' which call attention to the subject matter by suspending the progress of the narrative, are all, in structuralist terminology, foregrounding devices.

Dit is nodig om daarop te let dat die elemente asook die toepaslikheidsvoorwaardes (appropriateness conditions) doelbewus omvergewerp kan word as deel van die artistieke kwaliteite. Die skrywer en die leser ken egter die reëls en is dus daarop bedag.

Pratt se teorie gee 'n werkbare metode om die literatuur te ontleed. Ook verskaf die teorie genoegsame terminologie. In watter mate hierdie teorie ook met vrug binne die kreatiewe proses gebruik kan word, sal vervolgens aangedui word.

\section{4. 'n Praktiese toepassing van die teoretiese beginsels}

Die vraag wat uit bogenoemde bespreking voortvloei, is in welke mate dit moontlik sou kon wees om dié teoretiese raamwerk op die praktyk van die kinderverhaal toe te pas.

Daar word van die hipotese uitgegaan dat die elemente wat in die goedgestruktureerde mondelinge vertelling aanwesig is ook in die goedgestruktureerde kinderverhaal aangetref sal word. Die verband tussen die kinderverhaal self en die mondelinge vertelling lê onder andere daarin dat die kinderverhaal vir die drie- tot vyfjarige in 'n hoë mate nie werklik 'n leser in die gewone sin van die woord het nie. Die eindverbruiker, as die enigsins materiële tern verskoon kan word, van die kinderverhaal is in veel groter mate 'n hoorder as 'n leser. Die voorskoolse kind kan byvoorbeeld nie self as leser beskou word nie, want hy of sy hoor die verhaal. Hierdie feit lê 'n hegter band tussen die kinderverhaal en die mondelinge vertelling as wat byvoorbeeld vir die roman vir volwassenes sou geld.

As die elemente as een van die vereistes vir die geslaagde kinderverhaal gestel kon word, is dit dan verder moontlik om by die onderrig van Kinderliteratuur binne die vak Skryfkuns pertinent aandag te skenk aan die aard en funksie van die elemente. 


\subsection{Analise van gepubliseerde kinderverhale}

Drie gepubliseerde, Afrikaanse kinderverhale is geanaliseer met die doel om vas te stel of die geïdentifiseerde elemente hoegenaamd teenwoordig is.

Die drie tekste wat vir dié doel gebruik is, is: Jorsie - Sophie Muller (1991), Belladonna prima donna - Philip de Vos (1989) en Swart ster, wonderster versamelbundel Corlia Fourie (1993). Die tekste is gekies op grond van die feit dat hulle drie verskillende lesersgroepe verteenwoordig, naamlik Jorsie 3 - 5 jaar; Belladonna prima donna: 6-8 jaar en Swart ster, wonderster 8-10 jaar.

Uit die geanaliseerde verhale blyk dit dat die geidentifiseerde elemente wel teenwoordig is. Die elemente kom egter in 'n ander gestalte na vore as wat die geval is met die mondelinge vertelling. Dié gegewe kan teruggevoer word na die bespreking van Pratt wat dit duidelik stel dat die literêre werk bepaalde kwaliteite bevat wat aanleiding gee tot ' $n$ verskil in voorkoms wat die elemente aanbetref.

\subsubsection{Uittreksel}

In die kinderverhale was die voorkoms van die uittreksel telkens gekoppel aan die ouderdomsgroep vir wie die teks bedoel is. Dit wil voorkom asof ' $n$ uittreksel vir die ouderdomsgroep drie tot vyf jaar van belang is, maar nie in dieselfde mate as wat die uittreksel van belang is vir die ouderdomsgroep ses tot agt jaar nie. Laasgenoemde ouderdomsgroep kan 'n verhaal bloot kies op grond van die titel en die illustrasie op die buiteblad.

Die rol wat 'n illustrasie ten opsigte van die uittreksel speel, kan nie oorbeklemtoon word nie. Juis vanweë die feit dat daar in kinderliteratuur altyd 'n ryklik geillustreerde buiteblad is, bevestig ook die feit dat die uittreksel en die oriëntasie dikwels vervlegd voorkom.

Die feit dat talle kinderboeke met 'Eendag, lank, lank gelede' begin, speel ook ' $n$ rol ten opsigte van die uittreksel. Die tradisie van storievertel maak van laasgenoemde aanhaling nie alleen 'n oriëntasie ten opsigte van tyd nie, maar ook 'n uittreksel. In die voorleessituasie vind 'n mens dikwels dat die voorleser slegs met die aanhaling begin. Die hoorder is onmiddellik vasgevang in die storie, juis vanweë die feit dat hy vertroud is met die aanhaling en dit vir hom in 'n sekere sin bloot die standaardbegin van ' $n$ verhaal is.

Dit is opvallend dat al drie die verhale die hoofkarakter se naam in die titel het. By nadere ondersoek het dit geblyk dat dié wyse van titelgewing baie dikwels in kinderliteratuur voorkom. Vergelyk byvoorbeeld Abdoltjie - Alba Bouwer (1958), Nie so vinnig nie Songololo - Niki Daly (1985), Marcus en die boks- 
handskoene - Marquerite Poland (1984), Andreas en die grys heks - Estelle Bryer (1991) en Simonetta en die spinnekop - Elsabé Steenberg (1982).

\subsubsection{Oriëntasie}

Die oriëntasie van tyd en ruimte geskied in kinderliteratuur op ' $n$ baie vereenvoudigde manier.

Ten opsigte van tydshantering is dit opvallend dat die oriëntasie in kinderliteratuur nie gebruik maak van terugflitse nie. In Swart ster, wonderster van Corlia Fourie, word daar wel in sommige gevalle na die grammatiese verlede oorgeslaan, maar dit word op so ' $n$ wyse hanteer dat die leser bewus is van die feit dat dit die verlede van Swart Ster is (die rede waarom hy swart is en nie meer blink nie). Die tyd in Belladonna prima donna van Philip de Vos word baie eksplisiet benoem (twee dae, tien dae, ensovoorts). Dié wyse van tydsaanduiding is egter hanteerbaar vir die leser as gevolg van die kognitiewe vaardighede wat hy op dié ouderdom bereik het. Die effek wat hierdeur (die benoeming van tydsverloop) bereik word, is bloot dat die leser van die verbygaan van die tyd bewus is en dat dit in 'n sekere sin spanning bewerkstellig.

Jorsie van Sophie Muller laat by die leser/hoorder die gevoel van die verbygaan van tyd slegs as verloop.

Dit wil dus lyk asof aangekondigde tydsverloop nie vir die leser/hoorder op die ouderdom van drie tot vyf jaar kan slaag nie. Die leser/hoorder se kognitiewe vaardighede het in dié stadium nog nie in so 'n mate ontwikkel nie (vergelyk Schoeman \& Van der Westhuyzen, 1984:229).

Ten opsigte van ruimte val dit op dat die ruimtes telkens eerder beleef as beskryf word. Die rol wat illustrasies speel (veral dan ten opsigte van kinderliteratuur vir die ouderdomsgroep drie tot agt jaar), is opvallend. Die ruimte in die verhaal Jorsie was duidelik geillustreerd. Belladonna prima donna se ruimte is baie onmiddellik van aard en in dié opsig in 'n sekere mate beskryf.

Die oriëntasie ten opsigte van karakter speel in kinderliteratuur ' $n$ beduidende rol. Soos reeds genoem is, hoef die oriëntasie ten opsigte van die hoofkarakter (drie tot vyf jaar) nie daarop gemik te wees om identifisering met die hoofkarakter te bewerkstellig nie. Daar moet egter wel besliste duidelikheid wees rondom die hoofkarakter. Die vermoede bestaan dat bogenoemde alleen bewerkstellig kan word deur 'n verteller wat baie na aan die hoofkarakter staan.

Ten opsigte van die oriëntasie van karakter vir die ses- tot agtjarige wil dit voorkom asof karakteridentifikasie wel in 'n sekere opsig belangrik is. Hier is egter 'n 
belangrike aspek wat opval ten opsigte van die oriëntering van die hoofkarakter: die hoofkarakter se karaktertrekke word minimaal benut. Slegs een karaktertrek sal vir die doeleindes van die verhaal benut word. In dié verband was Belladonna prima donna en Swart ster, wonderster goeie voorbeelde.

Die belangrike ten opsigte van kinderliteratuur is dat die leser genoegsaam georiënteer moet word. In kinderliteratuur mag nie beskryf word nie, want die onmiddellike aard van die genre sal hierdeur aangeraak word, maar die leser moet dadelik (feitlik in die eerste paragraaf) weet wie die hoofkarakter is, wat die onmiddellike omgewing in samehang met die verwikkelde handeling en evaluering is, waaroor die storie gaan, en hoekom dit vertel moet word.

\subsubsection{Evaluering}

Evaluering, soos blyk uit die geanaliseerde verhale, kan geskied deur evaluerende kommentaar sowel as deur sintaktiese evaluering. Die wyse waarop evaluerende kommentaar in kinderliteratuur aangewend word, verskil vennoedelik van die wyse waarop Labov dit beskryf.

Ons insiens bedoel Labov (1976) dat die verteller sy eie ervarings deur evaluerende kommentaar evalueer. Kinderliteratuur maak egter merendeels van 'n ekstradiëgetiese verteller gebruik. Op grond van die feit dat die verteller baie na aan die hoofkarakter staan, kan gedeeltes geïdentifiseer word wat as evaluerende kommentaar beskou kan word.

Ten opsigte van sintaktiese evaluering val dit op dat dit veral die gebruik van die negatief, herhaling, dubbele attributiewe, verskillende leksikale naamwoordstukke met dieselfde verwysing asook verklarende beskrywings is wat algemeen voorkom. Hiermee word nie voorgegee dat die ander vorme nie bruikbaar is ten opsigte van kinderliteratuur nie. Die genoemde metodes het slegs algemeen in die geanaliseerde tekste voorgekom.

Baie opvallend is die rol wat evaluering speel by die dra van die boodskap asook die uiteindelike resultaat. In een geval kan daar met redelike sekerheid aangetoon word in watter mate die evaluering bygedra het tot die verstaan van die resultaat. In ' $n$ ander geval kon daar bepaal word dat daar ten opsigte van die verwikkelde handeling sowel as die oriëntasie nie genoegsaam geëvalueer is nie en die resultaat in 'n sekere opsig onbevredigend was.

\subsubsection{Verwikkelde handeling}

Die hantering van die element verwikkelde handeling is van deurslaggewende belang in kinderliteratuur. Uit die verhaal Jorsie en ander gelese werke vir die 
spesifieke ouderdomsgroep het dit duidelik geblyk dat die verwikkelde handeling baie eenvoudig van aard moet wees.

Ten opsigte van kinderliteratuur vir die ouderdomsgroep ses tot tien jaar val dit op dat die verwikkelde handeling meer gekompliseerd kan wees. Die hoofkarakter kan al probleemoplossend te werk gaan - in dié sin dat hy moontlike oplossings kan oorweeg.

\subsubsection{Die resultaat}

Die afsluiting of slot van ' $n$ kinderverhaal, of soos Labov (1976) dit stel: "the termination of events", is 'n gebied waaroor kinderboekskrywers verskil. Joan Aiken (1982:2) meen die volgende oor die afsluiting van 'n kinderverhaal:

A flat or unsatisfactory ending is the worst sin a writer can commit, it renders the whole book null and void. So the end, when it comes, must be strong, satisfying, yet perhaps with an element of surprise in it, ... .

Die geanaliseerde verhale voldoen aan al die vereistes wat gestel word vir 'n slot. 'n Belangrike aspek wat weer eens genoem kan word, is die rol wat evaluering speel ten opsigte van die resultaat. Dit lyk of die resultaat in kinderliteratuur baie sterk evaluerend moet wees. Die rede wat hiervoor aangevoer kan word, is dat evaluering ten opsigte van kinderliteratuur baie eksplisiet die boodskap van die verhaal dra. Die verhaal Swart ster, wonderster, bevestig in 'n sekere sin dié vermoede deurdat die uiteindelike resultaat nie duidelik is nie, omdat die evaluering van Swart Ster as die Bethlehemster nie tot die leser deurdring nie.

\subsubsection{Coda}

Slegs een van die verhale het 'n geleksikaliseerde coda gehad. Ons insiens besit Jorsie nie ' $n$ coda op grond van die teikenmark vir wie dit bedoel is nie. Die leksikale coda in dié teks is ook oorbodig.

Labov (1976) noem dat ' $n$ coda die opheffing is van die fiktiewe deiktiese sentrum. Vir die jong leser is dit egter nie problematies om te besef dat die verhaal op ' $n$ einde is nie. Steenberg (1979:4) is dan ook van mening dat die jong leser nie regtig ' $n$ probleem het met ' $n$ storie wat klaar vertel/gelees is nie. Dit bly 'n storie, al wil die leser/hoorder dit by herhaling weer hoor/lees.

Dit is goed moontlik dat elke verhaal, hetsy volwasseliteratuur of kinderliteratuur wél ' $n$ coda het. Selfs die toemaak van die boek en die einde van die leesproses sou as ' $n$ coda gesien kon word. 


\subsection{Afgekeurde manuskripte}

'n Hele aantal afgekeurde manuskripte is van verskillende uitgewers bekom. Hierdie manuskripte is aan die uitgewers as kinderverhale voorgelê.

Hoewel die manuskripte om verskillende redes afgekeur kan word, word daar in hierdie afdeling op die aard van die elemente in hierdie verhale gekonsentreer.

Die hipotese is dat ' $n$ minder geslaagde of ' $n$ mislukte kinderverhaal juis nie slaag nie, omdat daar iets skort met die elemente. In aansluiting by die res van die artikel, sou daar dus ' $n$ oordeel oor die belang van die elemente in die kinderverhaal uitgespreek kon word.

Dit blyk uit die analise (wat uiteraard ook beperk is deur die voorwaardes wat die uitgewers gestel het) dat die niegeslaagdheid van die manuskrip nie tot die gebrekkige gebruik van die elemente alleen teruggevoer kan word nie. Juis die feit dat die verhale nie slaag nie, bemoeilik die eksplisiete identifisering van die elemente self.

\subsubsection{Uittreksel}

Slegs in twee gevalle was die uittreksel problematies gewees. Die titels van dié twee manuskripte was hoegenaamd nie gerig op die kind nie. Die titels kan trouens as 'volwasse' bestempel word en het geen uitnodiging tot die bedoelde leser gerig nie.

\subsubsection{Oriëntasie}

Kenmerkend van feitlik al die manuskripte is dat die oriëntasie nie onmiddellik is nie. Heelwat ruimte is afgestaan aan die oriëntasie van persoon, tyd, ruimte en gebeure, terwyl dit voldoende sou wees om die leser te oriënteer slegs ten opsigte van die gegewens.

In 'n sekere geval is die oriëntasie van persoon, tyd en ruimte in totale isolasie van die ander elemente gedoen. Dié werkswyse het die verhaal laat inboet aan beweging in dié sin dat die leser nie kon bepaal waarom die verhaal vertel word nie.

Oriëntasie ten opsigte van persoon was in drie gevalle problematies in dié sin dat 'n karakter sonder enige aankondiging of motivering die verhaalwêreld betree het. Die leser kon in een geval glad nie aflei wie die karakter is nie. 


\subsubsection{Verwikkelde handeling}

Die grootste probleem ten opsigte van die elemente het gelê op die vlak van die verwikkelde handeling.

In teenstelling met die gepubliseerde verhale wat geanaliseer is, is die afgekeurde manuskripte se verwikkelde handeling gekenmerk deur te veel gekompliseerdheid en soms ' $n$ totale ongeloofwaardigheid.

Dit wil lyk of die keuse en aanbied van die verwikkelde handeling een van die probleemareas ten opsigte van kinderliteratuur is. 'n Hele aantal van die manuskripte was geensins gerig op die ervaringsveld van die kind nie.

\subsubsection{Evaluering}

Soos reeds genoem is, vorm evaluering 'n sekondêre struktuur. Dié feit impliseer dus dat daar spore van evaluering in al die elemente gevind kan word.

Problematies van al dié verhale was die feit dat bykans geen evaluering met oriëntasie saamgeval het nie. Die rede waarom die verhaal vertel word (the point of the story), het dus aanvanklik ontbreek.

In vier gevalle is die geheel gekenmerk deur die feit dat die leser nie kon bepaal wat die belang van die verhaal is nie.

Slegs in een geval (waarvan die uitgewer in die keurdersverslag genoem het dat die verhaal wél publiseermoontlikhede besit), is van evaluerende kommentaar gebruik gemaak.

\subsubsection{Resultaat}

Feitlik al die manuskripte het 'n resultaat vertoon wat uiters onbevredigend van aard is. In sommige gevalle was die resultaat só aangebied dat die leser nie die uiteinde met sekerheid kon bepaal nie.

In sekere gevalle is die les wat die verhaal wou leer totaal ongeèvalueerd as resultaat aangebied. Die werklike verhaalgebeure het dus nie voorop gestaan in die resultaat nie.

In twee gevalle is die resultaat gekenmerk deur 'n oorvereenvoudiging - die slot is dus opsigtelik so gestruktureer dat die leser dit moet verstaan. 
Al bogenoemde gebreke ten opsigte van die resultaat kan myns insiens aan een enkele rede toegeskryf word, naamlik die foutiewe hantering of afwesigheid van evaluering - veral dan in die resultaatgedeelte.

\subsubsection{Coda}

Nie een van die bestudeerde manuskripte het 'n geleksikaliseerde coda gehad nie. Die afleidings wat verwag is, kon nie bevredigend uit die korpus gemaak word nie. Waarskynlik is die gebrek aan gestruktureerdheid by die meerderheid van hierdie afgekeurde verhale ook daarvoor verantwoordelik dat die elemente as sodanig moeilik te analiseer is. Die hipotese van hierdie gedeelte kon nie bo alle twyfel wetenskaplik getoets word nie. Daar sou slegs gesê kan word dat gebrekkige hantering van die elemente een van die faktore is wat daarvoor verantwoordelik is dat 'n verhaal nie slaag nie. Met sekerheid kan egter gesê word dat die onderrig van die elemente oriëntasie, verwikkelde handeling en resultaat die verhale in sommige gevalle aansienlik sou kon verbeter.

Dit blyk dus uit die analises van die geslaagde kinderverhale asook die afgekeurde manuskripte dat die elemente inderdaad ook in die kinderverhaal sterk figureer. Dit sou dus teoreties moontlik wees om die elemente in die skeppingsproses aan te toon.

\section{Die ontwikkeling van 'n paradigma}

Syd Field (1982), bekende draaiboekskrywer en dosent in Skryfkuns, bestudeer draaiboeke en kom dan tot die gevolgtrekking dat 'n draaiboek sekere basiese struktuurelemente besit wat kenmerkend is van die genre

When I re-examined the 40 screenplays submitted to our partners ... I realized they all contained these basic concepts, regardless of how they were cinematically executed. They are in every screenplay. I began teaching this conceptual approach to writing the screenplay. If the student knows what a model screenplay is, I reasoned, it can be used as a guide or blueprint.

Field (1982:7) gebruik dan hierdie model as 'n paradigma by die skryf van draaiboeke. Paradigma omskryf hy as 'n model, patroon of "conceptual scheme". Die voorbeeld wat Field gebruik om 'n paradigma te verduidelik, is dié van 'n tafel naamlik dat ' $n$ tafel ' $n$ blad is met (gewoonlik) vier pote. Binne die paradigna is dit dan moontlik om 'n lang, ronde, ovaal, reghoekige, hoë of lae tafel te hê.

Die paradigma wat Field vir 'n draaiboek van 120 minute postuleer, vertoon diagrammaties soos volg: 


\begin{tabular}{|c|c|c|}
\hline$\frac{\text { beginning }}{\text { Act I }}$ & $\frac{\text { middle }}{\text { Act II }}$ & $\frac{\text { end }}{\text { Act III }}$ \\
\hline \multirow[t]{2}{*}{$\frac{\text { Setup }}{\text { pp. 1-30 }}$} & $\frac{\text { confrontation }}{\text { pp. } 30-90}$ & $\frac{\text { resolution }}{\text { pp. } 90-120}$ \\
\hline & $\frac{\text { oint I }}{-27}$ & $\frac{\text { point II }}{5-90}$ \\
\hline
\end{tabular}

Die begrip paradigma word binne hierdie artikel gebruik soos wat dit deur Field (1982) gebruik word. Die geïdentifiseerde elemente word as paradigma of model vir die skryf van 'n kinderverhaal gepostuleer.

Hierdie paradigma verteenwoordig slegs een stel dieptestruktuurreëls. Daarmee word nie veronderstel dat daar nie ander dieptestrukture vir kinderliteratuur bestaan nie - hierdie is slegs een besondere paradigma wat in dié artikel aan die orde kom.

Met die paradigma as ' $n$ dieptestruktuur word dan ' $n$ aantal aspekte as ' $n$ boboustruktuur veronderstel. Aspekte soos karaktertekening, die hantering/gebruik van fokalisasie, ensovoorts kan dus as deel van die toepassing van die boboustruktuur gesien word.

\subsection{Die geîdentifiseerde elemente as 'n paradigma}

Die vraag ontstaan egter waarom juis hierdie elemente van Labov as 'n paradigma gebruik word. Uit die navorsing van Labov is dit deurgaans duidelik dat nie een van sy segsmense bewus was van die elemente nie, maar Labov identifiseer wel hierdie elemente uit die segsmense se vertellings. In hierdie opsig is dus sprake van ' $n$ immanente struktuur - 'n soort oerpatroon wat op die lees van natuurlike kommunikasie geskoei is. In die bespreking van Pratt se siening ten opsigte van dié elemente is aangetoon dat die elemente gebruik kan word as 'n analisemiddel ten opsigte van volwasse literatuur. Pratt toon egter baie duidelik dat die grondbeginsel van hierdie elemente in volwasse literatuur soms (dikwels?) omvergewerp word as gevolg van die artistieke organisasie van die teks. In dié opsig is die kinderverhaal juis soveel nader aan die elemente. Kinderliteratuur veronderstel nie ' $n$ minderwaardige literatuur nie, maar eerder 'n literatuur/genre wat in 'n groot mate ' $n$ eenvoudiger struktuur moet gehoorsaam ter wille van die bedoelde leser. Dit is dan om dié redes dat die elemente van Labov as 'n paradigma vir die skryf van 'n kinderverhaal kan geld.

Die nut van die paradigma kan myns insiens tweërlei van aard wees: 
* Dit kan dien as 'n raamwerk waarbinne skeppend te werk gegaan kan word.

* Die student kan op grond van die verduideliking en bestudering van die paradigma (byvoorbeeld die oriëntasie in ' $n$ kinderverhaal is onmiddellik van aard) baie aflei oor dié spesifieke genre se aard.

\section{Die onderrig van die paradigma}

Dit is moontlik om die paradigma in ' $n$ beginstadium aan studente te verduidelik en te illustreer. Die student moet dus van meet af aan bewus wees van so 'n paradigma en hoe dit in kinderliteratuur funksioneer. Ervaring het bewys dat die paradigma werklik vir studente as ' $n$ soort raamwerk dien in die eerste stadium van skryf. Dit is in 'n sekere sin dus rigtinggewend.

In 'n werkswinkel sal die skryfteoretiese beginsels in samehang met die paradigma aan die orde kom. Die paradigma word in 'n werkswinkel gebruik die spesifieke werkswyse kan dan deur opdragte geillustreer word. Die teorie wat met die studente bespreek word, sowel as die skryfteoretiese beginsels, word met behulp van opdragte wat die studente moet uitvoer, prakties geillustreer. Studente kan in ' $n$ werkswinkel byvoorbeeld ' $n$ opdrag kry om 'n bestaande kinderverhaal se fokalisator te wysig, ensovoorts.

\section{Slot}

Deur uit te gaan van die teoretiese beginsels van die literatuurwetenskap en deur die toepassing van skryfteoretiese beginsels, sou daar dan vanuit die woordkunswerk self iets soos die paradigma waarom dit in hierdie artikel gaan, tot stand gebring kan word. Die paradigma hou dus rekening met die grondliggende teorie, maar dit staan ook vas in die praktyk van die gepubliseerde woordkunswerk.

Die insluiting van ' $\mathrm{n}$ middel soos die paradigma word daarom wetenskaplik verantwoord, maar dit vind terselfdertyd ook aansluiting by die praktyk. Dit is in die lig hiervan juis moontlik om dit in die onderrig van die skryfkuns te gebruik. Die ses elemente wat Labov onderskei en soos wat dit gebruik is in die analises van die verhale, kan daarom as 'n paradigma gebruik word wanneer die skryf van 'n kinderverhaal onderrig word.

Sonder om die paradigma as resep te probeer aanbied, bied die elemente ' $n$ breë raamwerk waarbinne 'n kinderverhaal geskep kan word. Dit moet daarom ook moontlik wees om die elemente as paradigma te gebruik by die skep van ' $n$ kinderverhaal. 


\section{Bibliografie}

Aiken, J. 1982. The Way to Write for Children. London : Elm Tree Books.

Anker, J. 1987. Die deiktiese ruimte as struktutrmiddel in Afrikaanse prosa. Kaapstad Universiteit van Kaapstad. (Ph.D -proefskrif.)

Bouwer, A. 1958. Abdoltjie. Kaapstad : Tafelberg.

Brink, A.P. 1979. 'n Droë wit seisoen. Emmarentia: Taurus.

Bryer, E. 1991. Andreas en die grys heks. Kaapstad : Tafelberg.

Cloete, T.T., red. 1992. Literêre terme en teorieë. Pretoria : HAUM-Literêr.

Combrink, J. 1981. Kom en gaan. (Referaat gelewer in 1981 by die Sewentiende Nasionale Kongres van LVSA.) Belville : Universiteit van Wes-Kaapland.

Daly, N. 1985. Nie so vimig mie, Songololo. Kaapstad : Human \& Rousseau.

De Vos, P. 1989. Belladonna prima domma. Kaapstad: Tafelberg.

Du Plessis, H. 1984. Die analise van 'n Griekwavertelling. In: Van Rensburg, M.C.J. (red.) Die Afrikaans van die Griekwas van die tagtigerjare. RGN-verslag. Band I. p. $640-$ 654.

Field, S. 1982. Screenplay. The Foundations of Screenplay. New York : Dell Publishing Co.

Fourie, C. 1993. Die wit vlinder. Kaapstad: Tafelberg.

Genette, G. 1979. Tijdsaspecten in de roman: volgorde, duur herhaling. Vertaal deur M.E. van Diepen. Brugge : Van Gorcum.

Johl, R. 1992. Teks en konteks. In: Cloete, T.T. (red.) Literêre terme en teorieë. Pretoria HAUM-Literêr. p. 530.

Labov, W. 1976. Language in the Immer City. Oxford : Blackwell.

Muller, S. 1991. Jorsie. Pretoria : Daan Retief.

Poland, M. 1984. Marcus en die bokshandskoene. Kaapstad: Tafelberg.

Pratt, M.L. 1977. Toward a Speech Act Theory of Literary Discourse. Bloominton Indiana University Press.

Prinsloo, S.M.C. 1987. Die struktuur van die mondelinge vertelling in Afrikaans. Potchefstroom: PU vir CHO. (D.Litt.-proefskrif.)

Schoeman, W.J. \& Van der Westhuyzen, T.W.B. 1984. Die middelkinderjare. In: Louw, D.A., Gerdes, L.C. \& Meyer, W.F. (red.) Menslike ontwikkeling. Pretoria : HAUM. p. 283-331.

Steenberg, E. 1979. My kind en sy boek. Goodwood : Tafelberg

Steenberg, E. 1982. Simonetta en die spinnekop. Kaapstad : Tafelberg.

Steenberg, E. 1992. Kinderliteratuur. In: Cloete, T.T. (red.) Literêre terme en teorieè. Pretoria : HAUM-Literêr. p. 202-204.

Theron, H.J. 1993. Die ontwikkeling van 'n paradigma vir die skryf van 'n kinderverhaal. Potchefstroom: PU vir CHO. (M.A.-verhandeling.)

Van Dijk, T. 1976. Pragmatics of langwage and Literature. Amsterdam : North Holland Publishers. 